Vol. 24, No. 4, pp. 411 423, 2021.

\title{
Application of Electrochemical Deposition in Solid Oxide Fuel Cell Technology
}

\author{
Jinwook Kim ${ }^{1 *}$, Hyunseung Kim ${ }^{1 *}$, Seongwoo Nam ${ }^{1 *}$, and WooChul Jung ${ }^{1 \dagger}$
}

${ }^{1}$ Department of Materials Science and Engineering, Korea Advanced Institute of Science and Technology (KAIST), 291

Daehak-ro, Yuseong-gu, Daejeon 34141, Republic of Korea

\section{전기화학 증착 기술과 고체산화물연료전지에의 응용}

\author{
김진욱 ${ }^{*}$, 김현승 ${ }^{*}$, 남성우 ${ }^{*}$, 정우철 ${ }^{\dagger}$ \\ 1한국과학기술원 (KAIST) 신소재공학과
}

(Received November 30, 2021; Revised December 24, 2021; Accepted December 24, 2021)

\begin{abstract}
s
This review paper describes the principle of electrochemical deposition and introduces recent studies applying it to the electrode fabrication of a solid oxide fuel cell (SOFC), a next-generation energy conversion device. Electrochemical deposition can easily control the structure and morphology of the deposition layer according to the applied bias/time/temperature, etc., and the process is very simple and possible even at low temperatures. In addition, deposition of cerium-based oxides, which are the representative ion-conductors or mixed-conductors widely used for SOFCs, is also possible via electrochemical deposition. To elucidate the effectiveness/novelty of electrochemical deposition, we present examples of the application of electrochemical deposition in SOFCs. Moreover, examples of using this method to study the properties of a material and/or to fabricate perovskite oxide-based electrodes are included.
\end{abstract}

Keywords: electrochemical deposition, solid oxide fuel cell, electrode

'Corresponding Author: wcjung@kaist.ac.kr

*This authors contributed equally. 


\section{1. 서론}

연료전지는 차세대 에너지 변환 장치로 그 중요성이 점점 커지고 있다. 다양한 종류의 연료전지 중 고체산화 물 연료전지 (solid oxide fuel cell, SOFC)는 다른 연 료전지에 비해 높은 에너지 효율과 연료 다변성의 장점 이 있다. 고체산화물 연료전지는 고체 상태인 연료극 (anode), 전해질 (electrolyte), 공기극 (cathode)로 구 성되어 있으며, 공기극에서는 식 (1)과 같은 반응이 일어 난다.

Cathode: $1 / 2 \mathrm{O}_{2}+2 e^{-}=\mathrm{O}^{2-}$

이때 cathode에서 공급된 산소 이온은 전해질을 통과 하여 anode로 공급된다.

대표적인 연료인 수소를 사용한 anode 반응은 다음과 같다. 식 (2)

Anode: $\mathrm{H}_{2}+\mathrm{O}^{2-}=\mathrm{H}_{2} \mathrm{O}+2 e^{-}$

각 전극에서 일어나는 반응과, 전해질을 통한 산소 이 온의 전도를 위해 고체산화물 연료전지는 주로 800도 이상의 높은 구동 온도에서 작동한다. 그러나 이러한 높 은 구동 온도는 장치의 열화 및 소형화에 악영향을 끼 친다. 따라서 중저온에서도 높은 활성을 가지는 고체산 화물 연료전지의 전극을 만들기 위해 다양한 물질을 코 팅하는 연구가 활발히 진행 중이다. 코팅을 통해 활성 이 높은 물질을 기존 전극 표면에 전기화학 촉매로 적용 하거나, 전극의 구조를 나노 미세 구조로 만들어 전극의 성능을 높일 수 있다. 고체산화물 연료전지 전극을 코팅 하는 방법으로 Infiltration, atomic layer deposition (ALD), chemical vapor deposition (CVD) 등 여러 가 지 코팅 방법이 사용되었다..$^{[1-3]}$ 근래에 들어서는, 앞서 언급한 다른 코팅공정과 비교하였을 때 상온 상압에서 의 공정 과정을 가지며, 빠른 속도로 대면적의 전극을 손쉽게 코팅할 수 있어 높은 산업적 가치를 지니는 전기 증착법, 특히 전기화학 증착법을 통해 고체산화물 연료
전지 전극에 코팅을 적용하고 있는 연구들이 부상하고 있다. 본 리뷰에서는 전기화학 증착에 관해 설명하고, 전기화학 증착을 통해 고체산화물 연료전지 전극의 내 구성 및 활성도를 증가시킨 연구 사례와 미래 활용도에 대해 살펴보겠다.

\section{2. 본론}

\section{1 전기화학 증착에 대한 이해}

전기증착 (Electrodeposition)은 전기도금 (Electroplating), 전기영동 증착 (Electrophoretic deposition, $\mathrm{EPD}$ ), 전기화학 증착 (Electrochemical deposition)을 포함한다. 세 가지 방식은 공통적으로 전 극에 전위차를 인가하여 코팅층을 형성한다는 점이 있 지만 (Table 1)과 같이 인가하는 전위, 증착된 물질의 형 태, 전해질 등의 차이점을 지닌다.

이 중 전기도금은 전해질 용액에 담긴 두 개의 전극 에 전원 공급 장치를 포함한 회로를 연결하여 수행되며, positive electrode (anode)에는 증착하려는 금속, 전기 도금이 이루어지는 negative electrode (cathode)에는 상대적으로 저렴한 금속이나 graphite와 같은 전도성 물질, 그리고 전해질로는 동일한 금속의 염 용액이 사용 된다. 전압을 인가하면 positive electrode의 금속은 산 화되어 양이온의 형태로 전해질 용액에 용해되며, 전자 는 회로를 통해 이동한다. Negative electrode에서는 회로를 통해 전원 공급 장치로부터 전자를 공급받아 전 해질 용액의 금속 양이온이 금속으로 환원된다. ${ }^{[5]}$

한편, 전기영동 증착에는 대전된 입자가 분산된 액체

Table 1. 전기도금, 전기영동 증착, 전기화학 증착의 이동 화학종, 증 착 과정의 전하 이동, 요구되는 매질의 전도도, 주로 사용 되는 매질에 따른 비교 ${ }^{[4]}$

\begin{tabular}{c|c|c|c}
\hline & 전기도금 & 전기영동 증착 & 전기화학 증착 \\
\hline 이동 화학종 & 이온 & 고체 입자 & 이온 \\
\hline $\begin{array}{c}\text { 증착 과정의 } \\
\text { 전하 이동 }\end{array}$ & 이온의 환원 & 없음 & $\begin{array}{c}\mathrm{O}_{2}, \mathrm{NO}_{3}^{-}, \mathrm{H}_{2} \mathrm{O} \\
\text { 의 환원 }\end{array}$ \\
\hline $\begin{array}{c}\text { 요구되는 매질의 } \\
\text { 전도도 }\end{array}$ & 높음 & 낮음 & 높음 \\
\hline 주로 사용되는 매질 & 물 & 유기 용매 & 물 \\
\hline
\end{tabular}


매질에 담긴 두 개의 전도성 전극 사이에 전기장이 인 가되며 수행된다. 전기영동 증착은 크게 두 단계로 이 루어지는데, 먼저 용액 속에 분산된 대전된 입자가 인 가된 전기장의 영향으로 반대 전하를 띄는 전극을 향 해 이동한다. 이후 입자들은 전극 위 상대적으로 균일 하게 밀도가 높은 박막의 형태로 증착된다. ${ }^{[6]}$ 양전하를 띤 입자의 증착이 negative electrode에 이루어지는 것 을 cathodic $\mathrm{EPD}$, 음전하를 띈 입자의 증착이 positive electrode에 이루어지는 것을 anodic $\mathrm{EPD}$ 라고 한다. 전기영동 증착의 경우 공정과 기구가 간단하며, 증착 기 판의 형태에 크게 구애받지 않는 등의 장점이 있지만, 액체 매질로 물을 사용할 수 없다는 단점이 있다. 전압 을 인가하였을 때, 수소 및 산소 가스가 발생하여 증착 물의 형상에 부정적인 영향을 끼치기 때문이다. ${ }^{[4]}$

전기화학 증착(Electrochemical deposition)은 전도 성 기판에 금속, 금속 산화물 및 금속 수산화물과 같은 다양한 물질을 코팅하는 데 유용한 방법이다. 전기화학 증착 또한 앞서 설명한 다른 전기증착과 마찬가지로 상 온, 상압 조건에서 증착하며 수용액 상에서 다양한 규모 의 시료에 적용할 수 있어 산업에 적용하기 매우 용이하 다. 다른 전기증착과 같이 타 코팅 기술에 비해 상대적 으로 빠른 코팅 속도를 가지며, 복잡한 장비나 공정을 필요로 하지 않는 간단한 방법이다. 또한, 증착 변수를 조정하여 코팅층의 조성, 미세 구조 및 두께를 정밀하게 제어할 수 있어 여러 가지 전기증착 방법 중 나노구조 의 코팅층을 만들기에 가장 적합한 방법이다. 전반적인 전기화학 증착법은 다음과 같은 과정으로 이루어진다. (Fig. 1)

먼저, 전극 표면에 cathodic bias가 인가되면 수용액 상의 전극 표면에서 식 (3)과 같은 반쪽 반응이 일어난 다.

$$
2 \mathrm{H}_{2} \mathrm{O}+2 e^{-}=2 \mathrm{OH}+\mathrm{H}_{2} \text { (gas) }
$$

이때, 전구체의 종류나 인가전압, 용액의 $\mathrm{pH}$ 도에 따 라 식 (4)과 같은 반응이 대신 일어날 수 있다.



Fig. 1. 전기화학 증착법을 통한 니켈, 세륨, 사마리움 수산화물 증착 메커니즘을 대략적으로 나타낸 그림

$$
\mathrm{NO}_{3}^{-}+\mathrm{H}_{2} \mathrm{O}+2 e^{-}=\mathrm{NO}_{2}^{-}+2 \mathrm{OH}
$$

이러한 반응을 통해 생성된 $\mathrm{OH}^{-}$이온은 전극 주위 의 $\mathrm{pH}$ 를 상승시키며, 용액 내 용해된 전구체와 결합 해 금속 수산화물로 형태로 식 (5)와 같이 침전하게 된다.

$$
M^{n+}+n O H=M(O H)_{n}
$$

침전된 금속 수산화물은 수용액 상에 용해되지 않고 고체 상태로 석출되어 전극 표면에 증착된다. 일반적으 로 수산화물 형태의 코팅층은 건조 과정 중 산화물의 형 태로 바뀐다. 이때, 인가하는 전압, 수용액 내 전구체의 농도, 용액의 온도 등을 조절하여 코팅층의 성장 거동 을 조절할 수 있으며, 최종적으로는 코팅층의 구조를 조 
특 집 표 김진욱, 김현승, 남성우, 정우철

절할 수 있다. 따라서 공정 변수와 성장 거동, 성장 거 동과 코팅층의 구조와의 관계성을 파악하는 것은 활용 목적에 적합한 코팅층을 제작하기 위해 반드시 선행되 어야 할 연구이다. 기존의 산화물의 전기화학 증착 성 장 거동을 규명하는 연구는 주로 성장 과정에 따른 코팅 층의 구조보다는 반응 경로나 결정화 과정을 규명하는 데 초점이 맞춰져 있었다. ${ }^{[7-10]}$ 그러나 전기화학 증착을 통한 고체산화물 연료전지 전극 표면 기능화를 위해서 는 해당 목적에 맞는 구조의 코팅층을 제작하는 것이 중 요하기 때문에 공정 변수에 따른 성장 거동과 최종적으 로 얻어지는 코팅층의 관계에 집중하여 최근 연구가 진 행되었다. ${ }^{[11]}$ 해당 연구에서는 세륨 산화물의 성장 거동 을 파악하기 위해 전기화학 증착 중 실시간으로 매우 정 밀한 질량 변화를 측정할 수 있는 석영 크리스탈 마이크 로 저울(quartz-crystal microbalance)과 일정하게 가 해진 전압 하에서의 실시간 전류밀도 분석 방법을 조합 하였다. 여러 가지 전압 조건에서 측정된 전류 밀도가
핵 생성 성장 모델과 확산 성장 모델 중 확산 성장 모델 에 부합하는 것을 확인하였고 이를 통해 전기화학 증착 을 통한 세륨계 산화물 성장 반응 과정이 핵 생성이 확 산에 비해 더 빠른 속도로 이루어지는 확산 지배적 성장 과정임을 확인하였다. 따라서 전체 전압을 적게 가해주 거나 낮은 온도에서 증착할 때, 전극으로부터의 확산영 역 (diffusion zone)이 줄어들게 되고, 이는 생성된 핵 이 기판에 증착될 때 무작위적인 증착이 아닌 에너지적 으로 선호되는 지점에 붙도록 유도되며, Fig. $2(\mathrm{a}-\mathrm{d})$ 와 같이 높은 인가전압에서 증착된 박막보다 낮은 인가전 압에서 증착된 박막이 특유의 나노구조를 가짐을 확인 하였다. 또한, 실제로 고체산화물 연료전지의 연료극에 코팅을 적용하였을 때, 앞서 보인 인가전압에 따른 코팅 층의 구조적 차이가 성능 변화에도 직접적인 영향을 준 다는 것을 확인하였다. Fig. 2 (e, f)

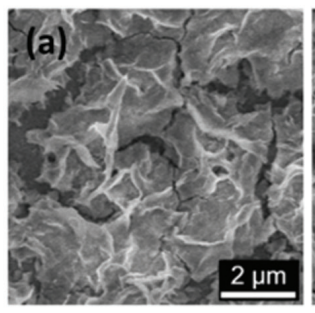

(e)

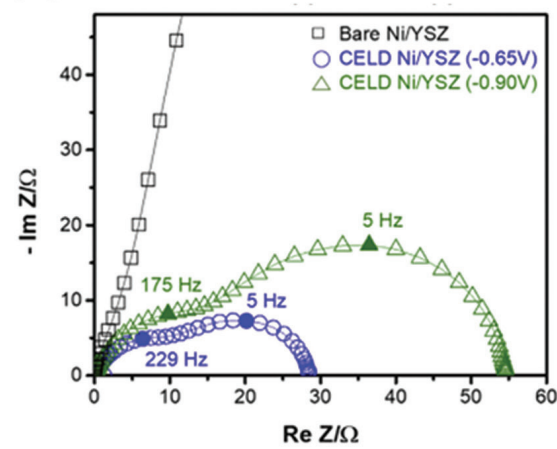

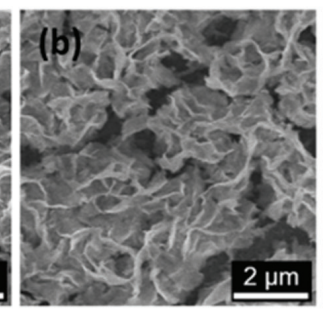
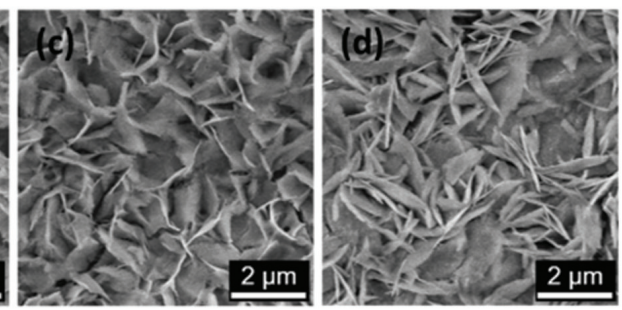

(f)

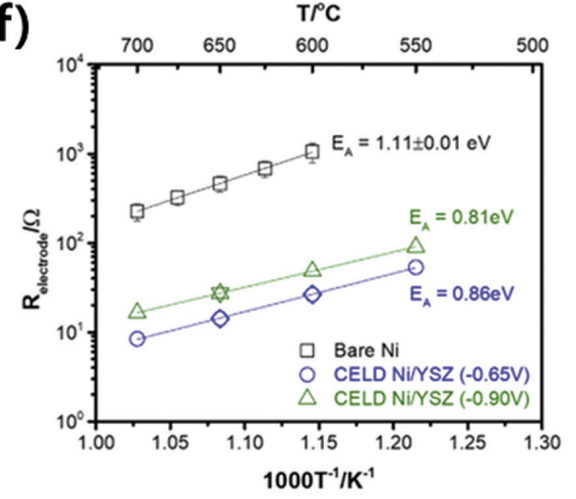

Fig. 2. (a-d) 전기화학 증착법을 이용해 제작한 인가 전압에 따른 세륨 산화물 박막의 표면 형상에 대한 주사전자현미경 이미지, (a) -0.90 V, (b) $-0.80 \mathrm{~V}$, (c) $-0.75 \mathrm{~V}$, (d) $-0.70 \mathrm{~V}$ vs. standard calomel electrode (SCE). (e) 전기화학 증착으로 코팅한 Ni/YSZ 전극을 사용한 대칭형 반쪽 전지의 전기화학 임피던스 스펙트럼 (electrochemical impedance spectrum, EIS) 및 (f) 이를 통해 추출한 전극 저항을 온도에 따라 나타낸 결과, adapted from Y. Choi et al. Eletrochim. Acta, 316 273-82 (2019), under the permission of Elsevier [11]. 


\section{2 전기화학 증착 기술의 고체산화물 연료전지 연료극으로의 응용}

고체산화물 연료전지의 연료극(Anode)으로는 니켈 (Ni)과 산화 이트륨이 도핑된 산화지르코늄 (YttriaStabilized Zirconia, YSZ) 복합체가 가장 널리 사용되 고 있다. 하지만 메탄과 같은 탄화수소연료를 이용한 작 동 시 $\mathrm{Ni} / \mathrm{YSZ}$ 복합체의 니켈 표면에 탄소 침적 현상이 일어나고, 이로 인해 성능이 저하되거나, 연료전지 셀이 파괴되는 현상이 발생한다. 이를 해결하기 위해서, 전기 화학 증착을 이용하여 니켈 표면에 탄소 침적에 대한 저 항성이 높고 연료극 분위기에서 높은 산소 이온 전도성 과 전자 전도성을 가지는 사마리움이 도핑된 세륨 산화 물 (Samarium doped $\mathrm{CeO}_{2}, \mathrm{SDC}$ )을 니켈 표면에 코 팅하는 연구가 시도되었다. ${ }^{[12]}$ 사마리움과 세륨 전구체 를 넣은 수용액 상에 $\mathrm{Ni} / \mathrm{YSZ}$ 전극을 넣어 약 1 분의 전 기화학 증착을 통해 약 $1 \mu \mathrm{m}$ 두께의 $\mathrm{SDC}$ 코팅층을 증 착하였다. 코팅을 통해 기존 니켈/YSZ/가스의 삼상계 면에 제한된 반응활성점이 코팅된 세리아 계면으로 확 장되어 650 도의 수소 환경에서 약 44 배, 메탄 환경에 서 약 8 배 전극 저항이 감소됨을 확인하였다. 뿐만 아니 라, 건식 메탄 환경에서 20 시간 내에 심각한 열화 현상 을 보인 $\mathrm{Ni} / \mathrm{YSZ}$ 와 다르게 전기화학 증착을 통해 코팅된 $\mathrm{Ni} / \mathrm{YSZ}$ 는 80시간 이상의 구동 시간에서 안정함을 보였 다. (Fig. 3 (a)) 탄소 침적의 영향은 Fig. 3 (b, c)에서 도 쉽게 볼 수 있듯이 코팅된 전극에 비해 bare Ni/YSZ 전극에서 훨씬 심하게 일어난 것을 볼 수 있다. 본 연구 는 최초로 수소뿐 아니라 탄화수소 연료에서도 고성능, 고내구성을 가지는 연료극 제작에 전기화학 증착 기술 을 활용할 수 있음을 보여주었다.

이와 같이 고체산화물 연료전지의 연료극에서의 성능 및 탄소 침적 저항성 개선을 위한 전략으로 전기화학 증 착법이 제시된 반면, 저온형 고체산화물 연료전지의 가 장 큰 문제점은 공기극의 느린 산소 환원 반응에 따른 큰 전극 저항 및 금속 기반 전극의 응집에 따른 낮은 안 정성이다. 이를 해결하기 위해 역시 전기화학 증착법을 활용하여 고체산화물 연료전지의 금속 기반 공기극을 개선하는 연구가 아래와 같이 진행된 바 있다.
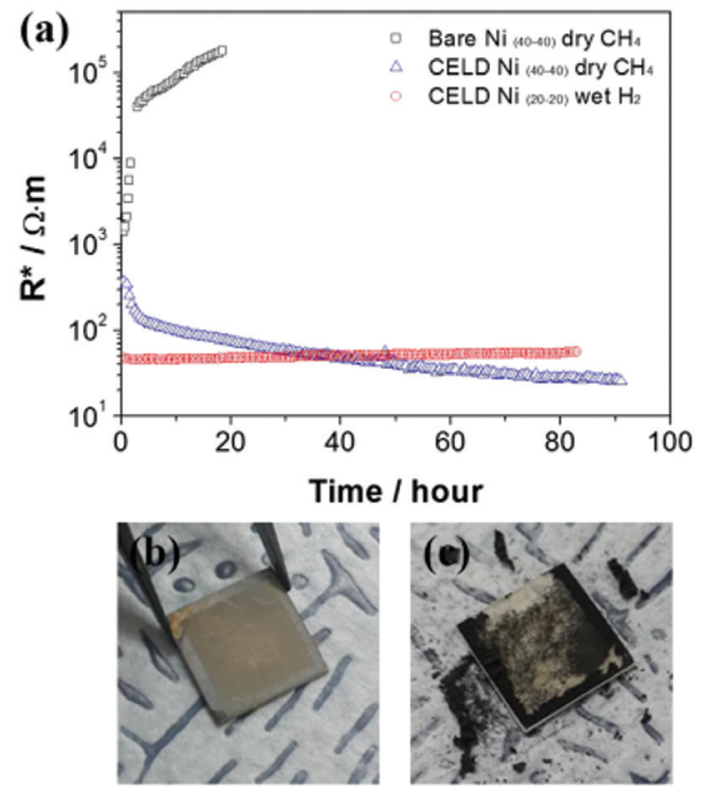

Fig. 3. (a) 구동 시간에 따른 건식 메탄 환경 및 습식 수소 환경에서의 bare Ni/YSZ 및 전기화학 증착법으로 코팅된 전극의 전극 저항 변화. 반응 이후 (b) 코팅된 전극의 모습과 (c) 심각한 탄소 침적이 일어난 bare Ni/YSZ 전극의 모습, adapted from Y. Choi et al. Nano Energy, 23 16171 (2016), under the permission of Elsevier [12].

\section{3 전기화학 증착 기술의 고체산화물 연료전지 공기극으로의 응용}

전기화학 증착법은 상온에서 전도성이 있는 scaffold 위에 진행된다는 특성 때문에 박막형 고체산화물 연료 전지 (Thin-film solid oxide fuel cells)의 금속 전극에 적용되었다. 박막형 고체산화물 연료전지는 일반적으로 수백 나노미터 이하의 전극 및 전해질을 통해 450도 이 하의 낮은 구동 온도에서 작동하기 때문에 저온에서의 산소 환원 반응에 대한 촉매 특성 및 전자 전도도가 우 수한 다공성 백금 전극을 산소극으로 활용하고 있다. 이 때 주요 반응 활성점은 공기-전극-전해질 삼상 계면이 며, 이 활성점의 밀도에 따라 산소 환원 반응에 의한 전 극 반응이 결정된다. 일반적인 혼합 전도성의 전극과 대 비되어 반응 활성점이 삼상계면에 한정된다는 단점이 있으며, 나노 공정을 통해 제작한 다공성 백금 전극은 고온의 환경에서 응집하여 삼상계면이 감소, 빠르게 열 화하는 특성이 있다. 이를 개선하기 위해 전기화학 증착 


\section{특 집 ㅍ 김진욱, 김현승, 남성우, 정우철}
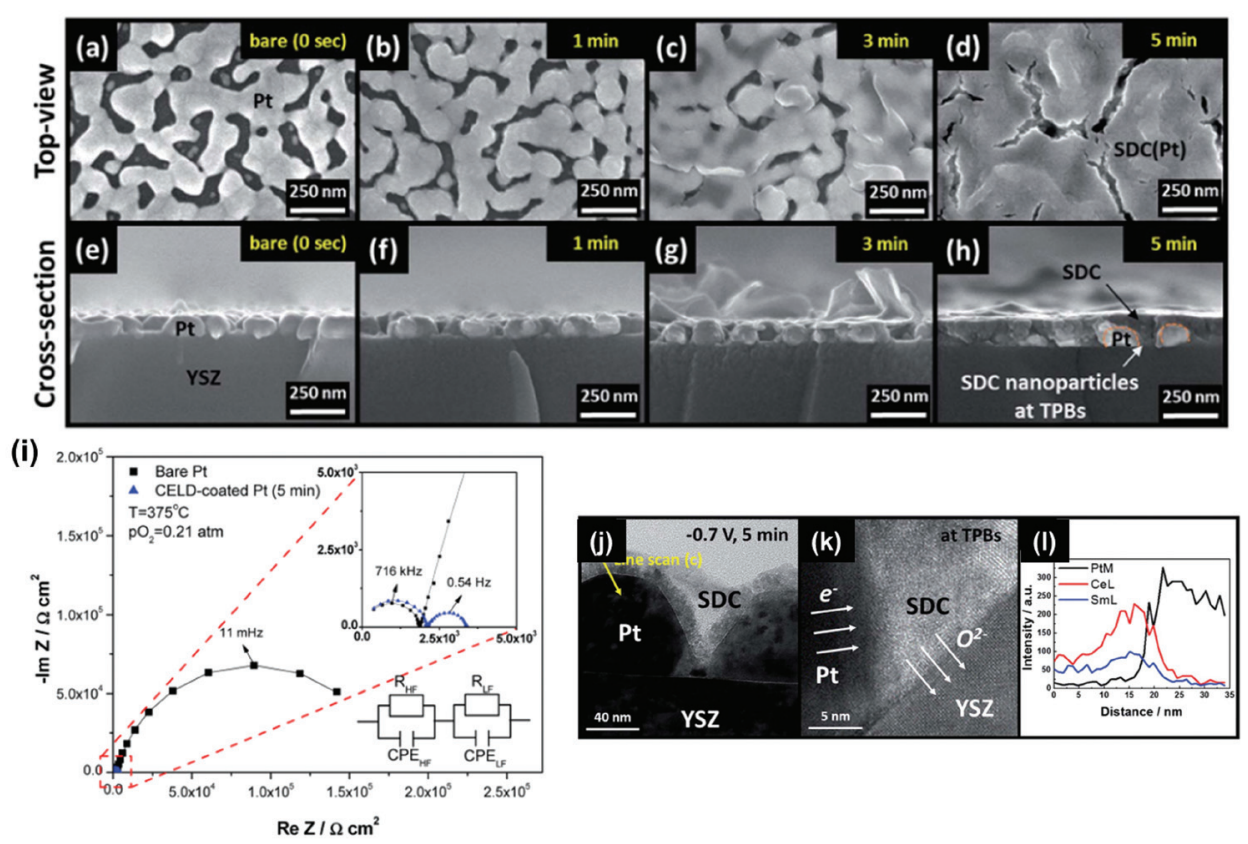

Fig. 4. 다공성 백금 전극 위 1-5 분 간 전기화학 증착법으로 코팅한 샘플의 (a-d) 평면 SEM 이미지 및 (e-h) 단면 주사전자현미경 이미지, 375도 및 0.21 기압의 산소 분압에서 실시한 백금 전극 및 전기화학 증착법으로 코팅한 세리아-백금 복합 전극을 사용한 대칭형 반쪽 전지의 전기화학 임피던스 스펙트럼, (j-I) 전기화학 증착법으로 코팅한 백금 전극의 투과전자현미경 이미지 및 에너지 분산형 X선 분광 line scan 결과, adapted from H. G. Seo et al. J. Mater. Chem. A, 4 [24] 9394-402 (2016), under the permission of RSC publishing [13].

공정을 통해 박막형 고체산화물 연료전지의 다공성 백 금 전극에 높은 표면적의 도핑된 세리아를 코팅하여 성 능 및 안정성을 크게 개선 연구가 발표된 바 있다. ${ }^{[13]}$

해당 연구에서 반응성 스퍼터링 및 환원 처리를 통 해 제작한 다공성 백금 전극에 대해 전기화학 증착법으 로 $\mathrm{SDC}$ 를 코팅한 결과를 보고했다. Fig. $4(\mathrm{a}-\mathrm{h})$ 에서 전기화학 증착 시간을 1-5 분으로 조절함에 따라 점점 두꺼운 코팅층이 증착되는 것을 확인할 수 있다. 또한 Fig. 4 (i)의 EIS 결과에서 전극 반응에 해당하는 저주파 수 영역 대의 임피던스 스펙트럼이 전기화학 증착 공정 이후 크게 감소한 것은 Fig. 4 (j-l)의 투과전자현미경 결과에서 볼 수 있듯이 다공성 백금 전극 사이로 증착된 $\mathrm{SDC}$ 코팅층이 전극의 삼상계면을 크게 증가 시켜 산소 환원 반응을 활성화한 것으로 볼 수 있다.

EIS으로부터 전극 활성도 $\left(1 / \mathrm{R}_{\text {electrode }}\right)$ 를 Fig. 5 (a, b) 와 같이 온도 및 산소 분압에 대해서 나타내보면 전기화 학 증착법으로 인한 $\mathrm{SDC}$ 코팅으로부터 반응 활성점이
크게 증가하여 전극 활성도가 100 배가량 증가했으며 산 소 분압에 대한 경향성을 통해 코팅층이 삼상계면을 증 가시킨 결과임을 볼 수 있다. 장기 구동 시 기존의 백 금 전극은 앞서 말한 응집 현상에 의해 Fig. 5 (c, e, f) 와 같이 꾸준히 오믹 저항에 해당하는 high-frequency semicircle 및 전극 저항에 해당하는 low-frequency semicircle의 크기가 증가, 성능이 열화하는 것을 볼 수 있으나 SDC를 코팅한 복합체 전극은 Fig. $5(\mathrm{~d}-\mathrm{f})$ 와 같 이 모든 저항 성분이 안정한 것을 볼 수 있다. 이는 전기 화학 증착 방식이 효과적으로 안정한 $\mathrm{SDC}$ 코팅층을 백 금 전극의 기공 사이로 증착하여 응집 현상을 방지한 것 으로 볼 수 있다.

또 다른 연구에서는 전기화학 증착 방식을 모델 백금 전극에 대해 $\mathrm{Pr}-$ doped 세리아 (PCO)를 증착하는 데 활 용하여 $\mathrm{PCO}$ 의 표면 반응성 및 전극으로의 활용 가능성 을 보인 결과를 보고했다. ${ }^{[14]}$ 이 연구에서는 다른 도핑 된 세리아와는 다르게 고온의 산화분위기에서 복합 전 
(a)

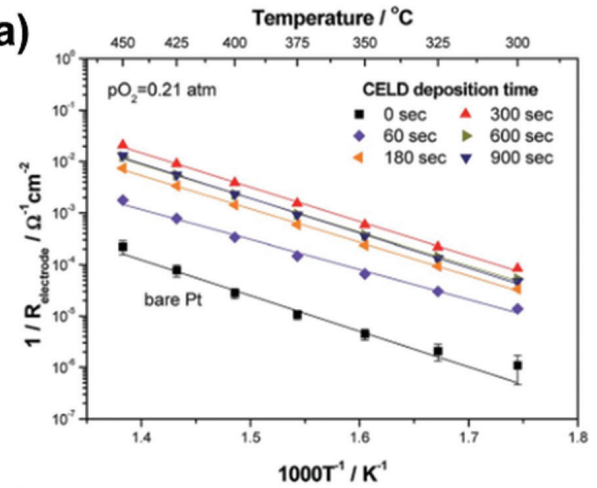

(c)

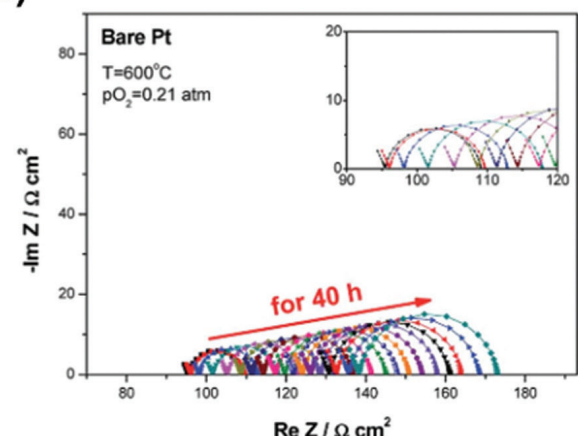

(e)

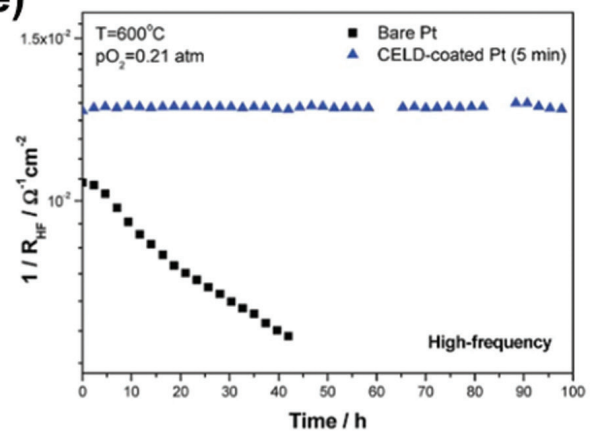

(b)



(d)

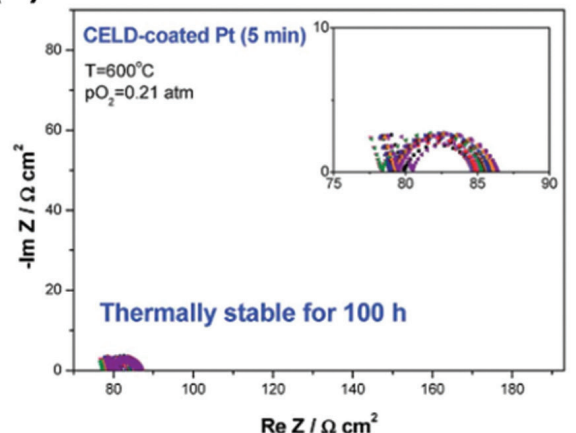

(f)

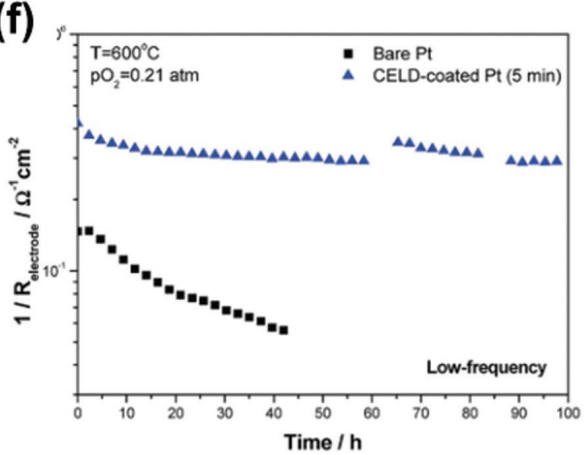

Fig. 5. (a) 온도 및 (b) 산소 분압에 따른 0-900 초 간 전기화학 증착법 코팅 처리된 다공성 백금 전극의 활성도 (1/전극 저항). 600도에서 측정된 시간에 따른 (c) 다공성 백금 전극과 $(\mathrm{d})$ 전기화학 증착된 백금 전극을 사용한 대칭형 반쪽 전지의 $\mathrm{EIS} \mathrm{결과} \mathrm{및} \mathrm{각} \mathrm{전극의}$ (e) 고주파수 영역과 (f) 저주파수 영역 성분을 시간에 따라 나타낸 그림, adapted from H. G. Seo et al. J. Mater. Chem. A, 4 [24] 9394-402 (2016), under the permission of RSC publishing [13].

도도 (전자 및 이온 전도도)를 지니는 $\mathrm{PCO}$ 의 산소 환원 반응에 대한 활성도를 측정하고 고체산화물 연료전지 공기극 물질로서의 활용성을 밝히기 위해 Fig. $6(\mathrm{a}-\mathrm{d})$ 와 같이 띠 형태의 백금 모델 전극 위에 매우 표면적이 큰 $\mathrm{PCO}$ 코팅층을 증착했다. 인가한 전압에 따라 코팅 층의 구조를 다양화할 수 있는 전기화학 증착법의 특성 을 활용해 표면적이 넓은 $\mathrm{PCO}$ 코팅층을 증착할 수 있었
다(Fig. 6 (c)). 전기화학 임피던스 스펙트럼의 전극 반 응에 해당하는 신호에 대해 두 개의 semicircle로 피팅 을 진행하여 충전 용량이 산소 분압과 경향성을 지니는 $\mathrm{PCO}$ 표면 반응과 경향성이 없는 $\mathrm{PCO}$ 백금 |공기 삼상 계면 반응을 분리했으며, 이 중 $\mathrm{PCO}$ 표면 반응성이 매 우 우수하다는 것을 관측하였다. (Fig. $7(\mathrm{a}-\mathrm{c})$ ) 또한 전 기화학 증착법을 통해 증착한 $\mathrm{PCO}$ 코팅층은 높은 표면 


\section{특 집 ㅁㅁㅁㅣㅣㅁ진욱, 김현승, 남성우, 정우철}

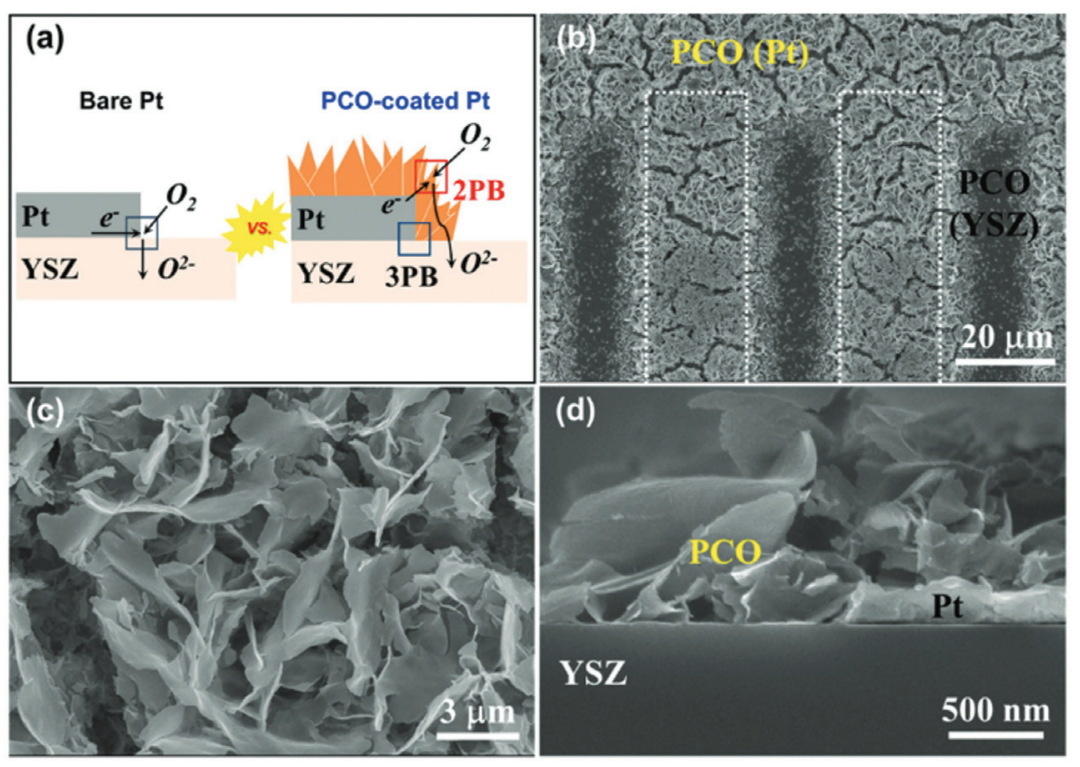

Fig. 6. (a) 박막형 백금 모델 전극 위 Pr-doped 세리마 (PCO)를 전기화학 증착하는 모식도 및 이에 대한 (b-d) 주사전자현미경 이미지, adapted from H. G. Seo et al. Adv. Energy Mater., 8 [19] 1703647 (2018), under the permission of Wiley [14].
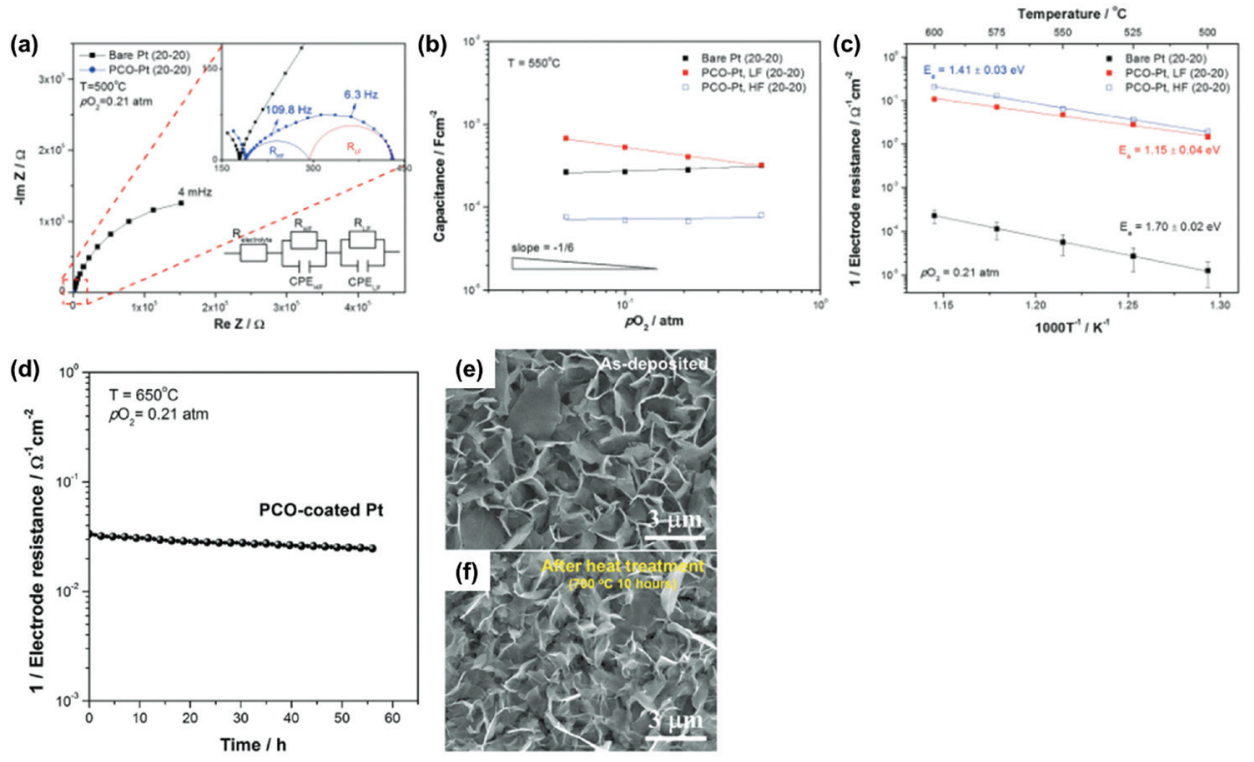

Fig. 7. (a) Bare 백금 모델 전극 및 PCO 코팅된 전극으로 구성된 대칭형 반쪽전지의 EIS 결과 및 이를 피팅해 측정한 (b) 산소 분압에 따른 각 성분의 충전용량 경향, (c) 온도에 따른 전극 활성도 경향. (d) 650 도에서 50 시간 이상 측정한 전극 활성도 및 (e, f) 열처리 전후 주사전자현미경 이미지, adapted from H. G. Seo et al. Adv. Energy Mater., 8 [19] 1703647 (2018), under the permission of Wiley [14].

적에도 불구하고 열적으로 안정하여 Fig. 7 (d, e)과 같 이 50 시간 이상 안정함을 볼 수 있었다. 이런 결과는 전기화학 증착법이 단순히 고체산화물 연료전지 공기극
의 성능과 안정성을 향상시킬 수 있음과 더불어 새로운 물질의 전극 활용 가능성을 평가하기 위한 모델 플랫폼 을 제작할 수 있는 기술임을 보여준다. 

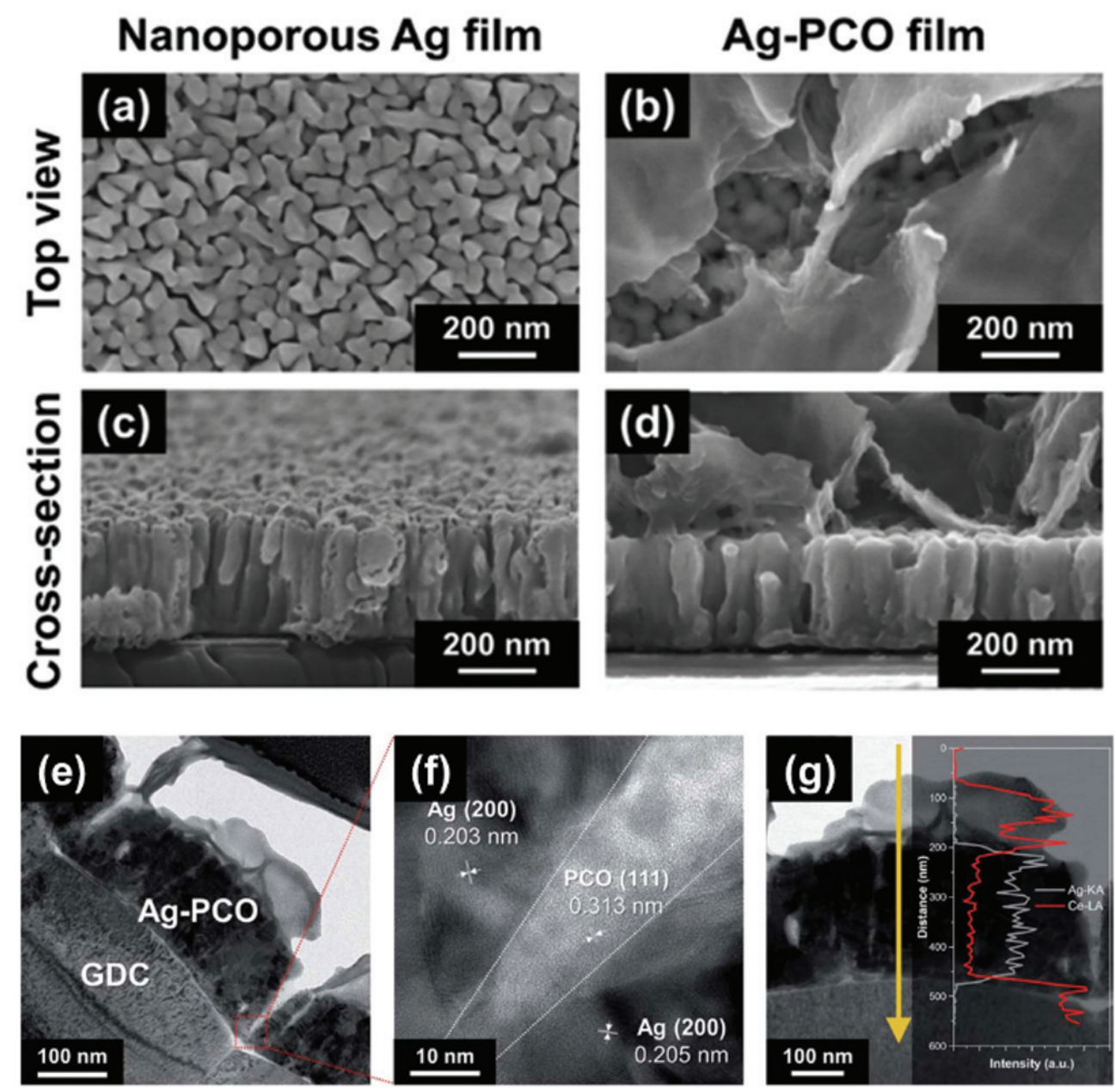

Fig. 8. (a, c) 다공성 은 전극 및 $(\mathrm{b}, \mathrm{d})$ 전기화학 증착법으로 $\mathrm{PCO}$ 를 코팅한 은 전극의 주사전자현미경 이미지. (e-g) PCO 코팅된 은 전극의 투과전자현미경 이미지 및 에너지 분산형 X선 스펙트럼, adapted from H. Kim et al. J. Mater. Chem. A, 8 [29] 14491-7 (2020), under the permission of RSC publishing [15].

이후 전기화학 증착법의 활용 가능성을 고체산화물 연료전지의 은 전극에도 적용하여, 백금보다 저렴하지 만 저온에서 매우 좋은 산소 환원 반응성을 지닌 다공성 은 전극의 성능 및 안정성을 증가시킨 결과 또한 보고되 었다. ${ }^{[15]}$ 본 결과에서는 기존 다공성 백금 전극의 수십 나노미터 크기의 비교적 넓은 기공뿐 아니라 Fig. 8 (a, c)의 매우 좁은 다공성 은 전극의 기공까지 Fig. 8 (b, d)와 같이 증착이 가능하다는 의의를 지니며 이는 Fig. $8(\mathrm{e}, \mathrm{g})$ 에서도 확인할 수 있다.

이는 다공성 금속 박막과 더 높은 친화도를 지니게 하 기 위해 전해질 용액에 에탄올을 첨가하여 작은 기공 사
이로도 코팅이 가능하게 하였기 때문이며, 이렇게 작은 기공 사이를 채운 전기화학 증착 코팅층은 삼상계면을 크게 증가시켜 성능을 향상시켰을 뿐만 아니라 (Fig. 9 (a-b)) 백금보다 훨씬 더 열적 안정성이 떨어지는 은 전 극 역시 그림과 같이 가속된 환경에서도 50 시간 이상 전 혀 열화 없이 안정화시켰다. (Fig. $9(\mathrm{c}-\mathrm{d})$ ) 또한 전기화 학 증착법은 몇 분 내로 상온 상압의 환경에서도 대면적 적용이 가능한 장점이 있어 실제 전해질 지지체형 고체 산화물 연료전지에 적용이 가능하다. 이는 실제로 Fig. 9 (e)의 결과에서 약 $30 \%$ 이상 성능이 향상된 것으로 증 명되었다. 

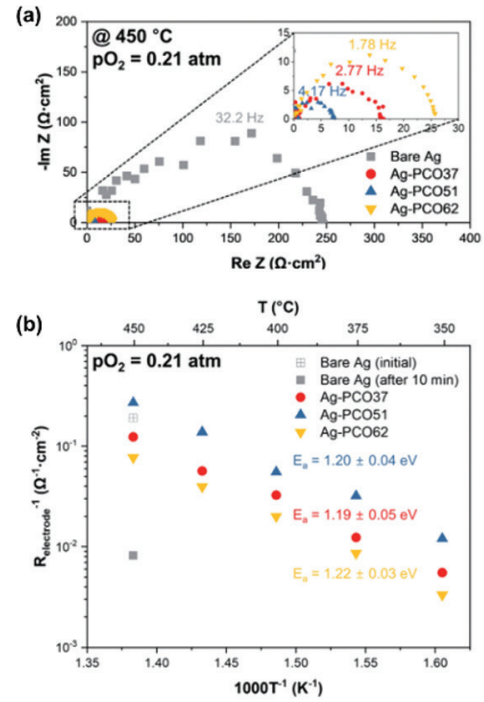

(c) Bare Ag @ $450{ }^{\circ} \mathrm{C}$

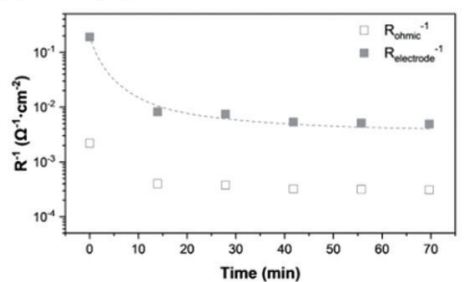

(d) CELD-treated Ag @ $550{ }^{\circ} \mathrm{C}$

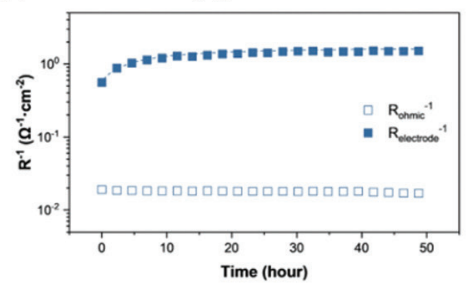

(e)

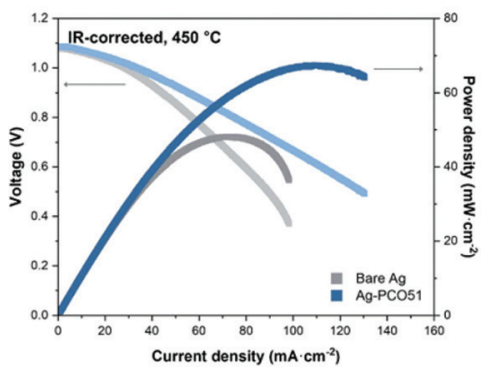

Fig. 9. (a) 450도, 0.21 기압 산소 분압에서 측정한 전기화학 증착 시간에 따른 Ag-PCO 복합체 전극을 사용한 대칭형 반쪽전지의 티 결과 및 이를 피팅하여 계산한 (b) 온도별 전극 활성도. (c) bare 은 전극 및 (d) Ag-PCO 복합체 전극의 활성도를 시간에 따라 나타낸 결과. (e) 전기화학 증착 적용 유무에 따른 SDC 전해질 지지체형 단전지의 I-V-P 곡선 (anode: porous Pt), adapted from H. Kim et al. J. Mater. Chem. A, 8 [29] 14491-7 (2020), under the permission of RSC publishing [15].

Rehman 등의 연구자는 같은 원리를 이용해 chemically assisted electrodeposition (CAED)라는 이름으로 다공성 페로브스카이트계 전도성 산화물을 제 작했다. $\mathrm{CAED}$ 공정을 위해 carbon nanotube (CNT) 를 ScCeSZ scaffold 위에 chemical vapor deposition (CVD) 방식으로 증착하고 그 위에 전기화학 증착법을 적용했다. (Fig. 10) 전해질 용액 속 $\mathrm{La}^{3+}$ 와 전이금속 이온의 농도비를 조절하여 $\mathrm{La}-\mathrm{TM}-\mathrm{OH}$ 를 fiber의 형 태로 제작하였고 열처리를 통해 다공성의 $\mathrm{LaNiO}_{3}{ }^{[16]}$, $\mathrm{LaCoO}_{3}{ }^{[17]}, \mathrm{La}(\mathrm{Ni}, \mathrm{Fe}) \mathrm{O}_{3}{ }^{[18]}$ 전극을 제작했다. 이렇게 제 작된 페로브스카이트계 산화물 전극은 Fig. 11 (a, b)와 같이 매우 비표면적이 큰 다공성의 구조로 제작되었으 며, Fig. 11 (c, d)의 결과에서 볼 수 있듯이 실제 단전지 에 적용되었을 때 성능과 안정성이 우수했다.

\section{4 전기화학증착을 통한 고체산화물연료전지 연구의 한계점 및 미래 발전 방향}

전기화학 증착의 가장 큰 문제점은 scaffold에 상온에 서의 높은 전자 전도도가 요구된다는 것이다. 그렇기 때
문에 지금까지 전기화학 증착을 고체산화물 연료전지에 적용한 연구는 금속 기반 전극, 특히 박막형 고체산화 물 연료전지의 공기극(백금, 은)에 주로 활용되었다. 하 지만 금속 기반 전극은 600 도 이상의 고온에서 낮은 안 정성을 보이기 때문에, 일반적인 고체산화물 연료전지 에서는 주로 페로브스카이트계 산화물 기반 전극이 사 용된다. $\mathrm{CAED}$ 를 통해 페로브스카이트계 산화물 전극을 제작한 연구는 있지만, 이 또한 높은 상온 전도도를 가 지는 CNT scaffold의 형성을 위해 infiltration과 CVD 와 같은 추가적인 공정을 필요로 한다. 또한, 전극 물 질의 성능을 개선할 수 있는 것은 아니며, 일부 원소만 이 전기화학 증착이 가능하므로 제작 가능한 전극의 종 류가 제한적일 수밖에 없다. 또한 전기화학 증착을 통해 페로브스카이트계 산화물과 같은 다종 양이온 구조체를 형성하는 경우, 원소마다 증착률이 달라 용액과 증착 구 조체에서의 조성이 일치하지 않으며, 원하는 조성의 구 조체를 형성하기 위한 최적화 과정이 필요하다. 따라서 향후에는 상온 전도성을 지닌 페로브스카이트계 산화물 기반 전극에 직접적으로 전기화학 증착을 적용하여 전 


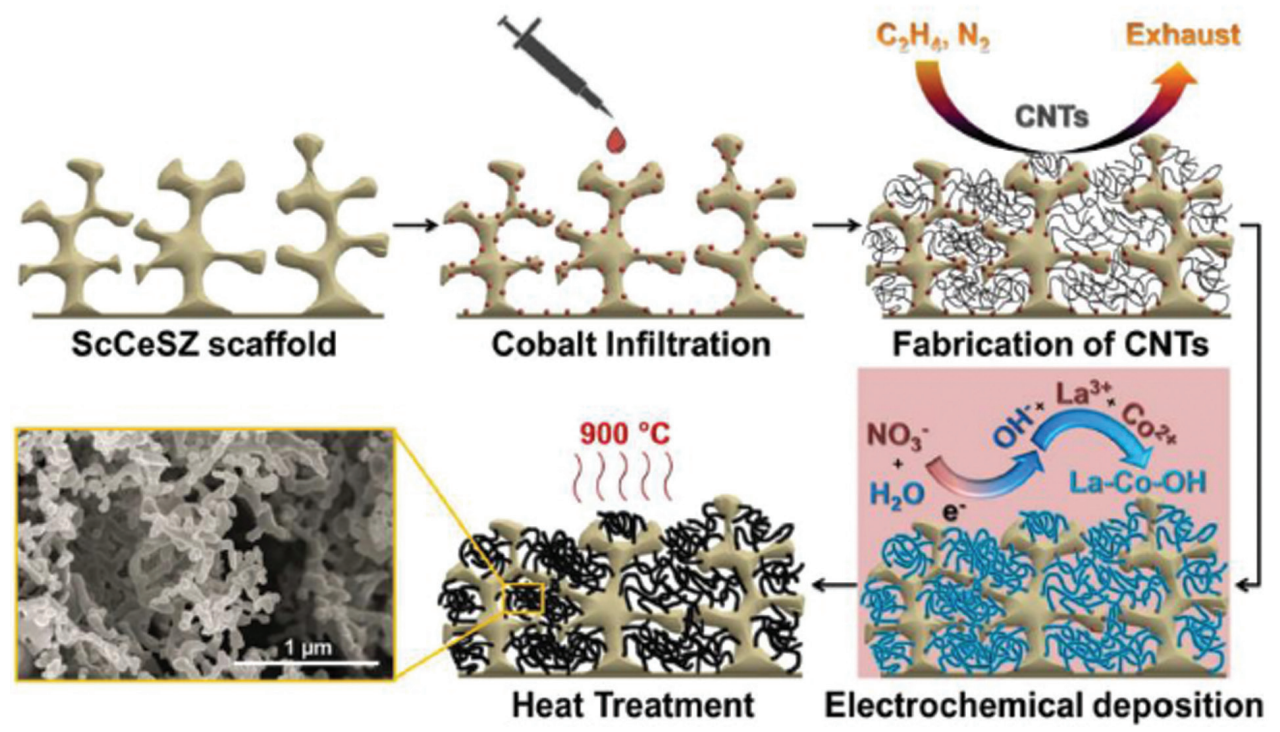

Fig. 10. 전기화학 증착법을 이용해 다공성 페로브스카이트계 산화물 전극을 제작하는 방법, adapted from S. U. Rehman et al. J. Mater. Chem. A, 6 [16] 6987-96 (2018), under the permission of RSC publishing [16].
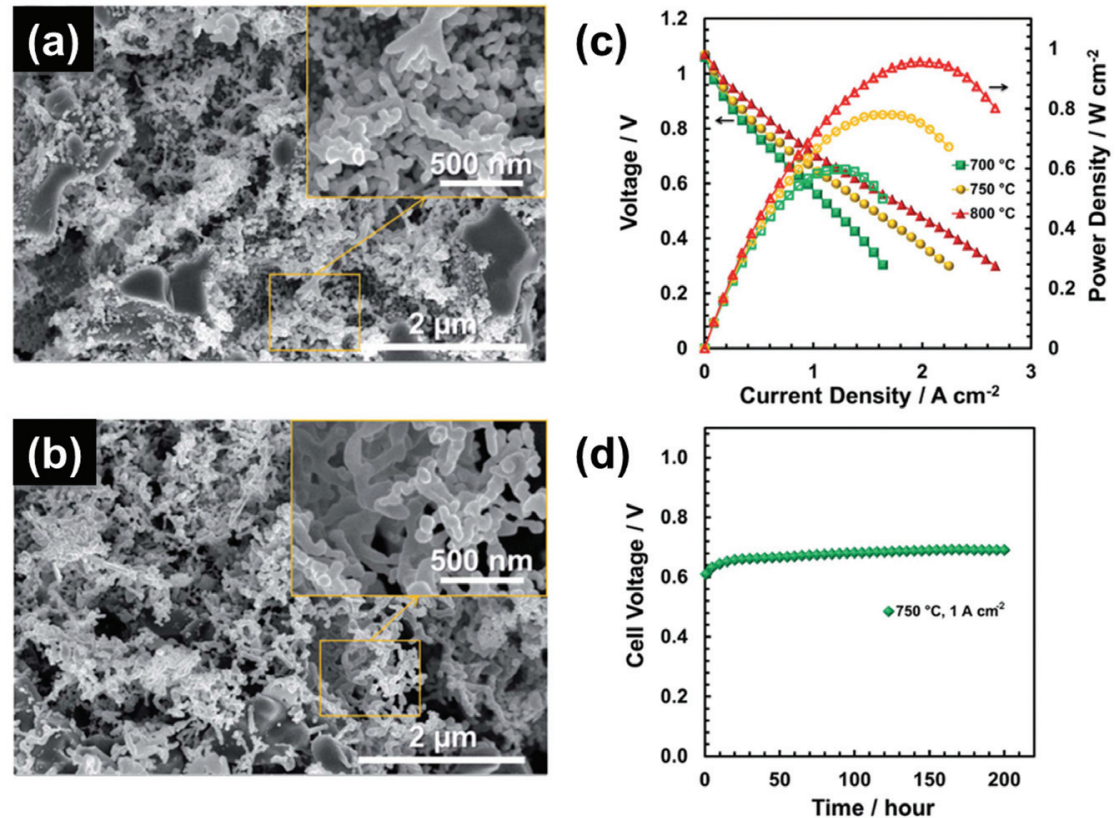

Fig. 11. (a, b) 전기화학 증착법을 통해 제작한 $\mathrm{LaCoO}_{3}$ 전극의 주사전자현미경 이미지, 및 (c) 이를 통해 제작한 $\mathrm{NiO}-\left(\mathrm{Sc}_{2} \mathrm{O}_{3}\right)_{0.1}\left(\mathrm{CeO}_{2}\right)_{0.01}$ $\left(\mathrm{ZrO}_{2}\right)_{0.89}$ anode 지지체형 단전지의 I-V-P 결과, (d) 750도 안정성 테스트 결과, adapted from S. U. Rehman et al. J. Mater. Chem. A, 6 [16] 6987-96 (2018), under the permission of RSC publishing [16].

극의 성능을 개선할 수 있는 연구가 진행될 것으로 예측 된다. 그러나 산화물은 일반적으로 상온에서 금속에 비 해 낮은 전자 전도도를 가지기 때문에, 전기화학 증착을
적용할 수 있는 산화물은 극히 제한적일 것으로 예상되 며. 작은 기공을 가진 다공성 산화물 구조체에 균일하게 증착하는 것은 추후 연구자들이 해결해야할 숙제이다. 


\section{3. 결론}

본 리뷰 논문은 전기화학 증착법의 기본적인 메커니 즘과 이를 이용해 차세대 에너지 변환 장치로써 큰 관심 을 받고 있는 고체산화물 연료전지의 전극에 활용된 사 례들을 소개한다. 전기화학 증착법은 다른 전기증착과 는 증착된 물질의 형태와 전하 이동 과정 등에서 차이점 을 보이며, 인가전압/시간/온도 등에 따라 증착층의 구 조와 형태를 쉽게 조절할 수 있다는 장점이 있다. 또한, 기존의 다양한 코팅법에 비해 공정이 매우 간단하고 저 온에서도 가능하다는 점, 그리고 고체산화물 연료전지 로 많이 사용되는 세륨계 산화물 증착이 가능하다는 점 을 이용해 이를 고체산화물 연료전지 연료극 및 공기극 개선 전략으로 사용한 연구들을 소개했다. 또한, 단순히 이미 사용되는 전극에 코팅을 통해 개선하는 것뿐만 아 니라, 모델 전극에 전기화학 증착법을 적용하여 신물질 의 특성을 분석하는 새로운 연구 방향이나, 페로브스카 이트계 산화물 소재의 다공성 전극을 제작할 수 있는 기 술임을 보였다.

\section{REFERENCES}

1. D. Ding, X. Li, S. Y. Lai, K. Gerdes, and M. Liu, "Enhancing SOFC cathode performance by surface modification through infiltration," Energy Environ. Sci., 7 [2] 552-75 (2014).

2. J. Seo, N. Tsvetkov, S. Jeong, Y. Yoo, S. Ji, J. H. Kim, J, K, Kang, and W. Jung, "Gas-Permeable Inorganic Shell Improves the Coking Stability and Electrochemical Reactivity of Pt toward Methane Oxidation," ACS Appl. Mater. Interfaces, 12 [4], 4405-13 (2020).

3. D. Y. Jang, G. D. Han, H. R. Choi, M. S. Kim, H. J. Choi, and J. H. Shim, "La0.6Sr0.4Co0.2Fe $0.8 \mathrm{O} 3-\delta$ cathode surface-treated with $\mathrm{La} 2 \mathrm{NiO} 4+\delta$ by aerosol-assisted chemical vapor deposition for high performance solid oxide fuel cells," Ceram. Int., 45, [9] 12366-71 (2019).

4. L. BESRA and M. LIU, "A review on fundamentals and applications of electrophoretic deposition (EPD)," Prog. Mater. Sci., 52 [1] 1-61 (2007).
5. M. Schlesinger and M. Paunovic, Eds., "Modern Electroplating"; John Wiley \& Sons, Inc., 2010.

6. A. R. Boccaccini and I. Zhitomirsky, "Application of Electrophoretic and Electrolytic Deposition Techniques in Ceramics Processing. Part 1.," ChemInform, 36 [46] 242-6, (2005).

7. A. J. Aldykiewicz, A. J. Davenport, and H. S. Isaacs, "Studies of the Formation of Cerium-Rich Protective Films Using X-Ray Absorption Near-Edge Spectroscopy and Rotating Disk Electrode Methods," J. Electrochem. Soc., 143 [1] 147-54 (1996).

8. Y. Zhou and J. A. Switzer, "Growth of cerium(IV) oxide films by the electrochemical generation of base method," J. Alloys Compd., 237 [1-2] 1-5 (1996).

9. F.-B. Li, R. C. Newman, and G. E. Thompson, "In situ atomic force microscopy studies of electrodeposition mechanism of cerium oxide films: nucleation and growth out of a gel mass precursor," Electrochim. Acta, 42 [16] 2455-64 (1997).

10. L. Čerović, V. Lair, O. Lupan, M. Cassir, and A. Ringuedé, "Electrochemical synthesis and characterization of nanorods, nanocolumnar ceria based thin films on different glass substrates," Chem. Phys. Lett., 494 [4-6] 237-42 (2010).

11. Y. Choi, J. Kim, H. G. Seo, H. L. Tuller, and W. Jung, "Nucleation and growth kinetics of electrochemically deposited ceria nanostructures for high-temperature electrocatalysis," Electrochim. Acta, 316 273-82 (2019).

12. Y. Choi, E. C. Brown, S. M. Haile, and W. Jung, "Electrochemically modified, robust solid oxide fuel cell anode for direct-hydrocarbon utilization," Nano Energy, 23 161-71 (2016).

13. H. G. Seo, Y. Choi, B. Koo, A. Jang, and W. Jung, "Robust nano-architectured composite thin films for a low-temperature solid oxide fuel cell cathode," $J$. Mater. Chem. A, 4 [24] 9394-402 (2016).

14. H. G. Seo, Y. Choi, and W. Jung, "Exceptionally Enhanced Electrode Activity of $(\mathrm{Pr}, \mathrm{Ce}) \mathrm{O} 2-\delta$-Based Cathodes for Thin-Film Solid Oxide Fuel Cells," $A d v$. Energy Mater, 8 [19] 1703647 (2018).

15. H. Kim, H. G. Seo, Y. Choi, D.-K. Lim, and W. Jung, "Cathodic electrochemical deposition: a new strategy to enhance the activity and stability of silver cathodes for thin-film solid oxide fuel cells," J. Mater. Chem. $A, 8$ [29] 14491-7 (2020). 
16. S. U. Rehman et al., "High-performance nanofibrous LaCoO 3 perovskite cathode for solid oxide fuel cells fabricated via chemically assisted electrodeposition," J. Mater. Chem. A, 6 [16] 6987-96 (2018).

17. S. U. Rehman et al., "Nano-fabrication of a highperformance $\mathrm{LaNiO} 3$ cathode for solid oxide fuel cells using an electrochemical route," J. Power
Sources, 429 97-104 (2019).

18. A. Shaur et al., "Hybrid Electrochemical Deposition Route for the Facile Nanofabrication of a Cr-Poisoning-Tolerant $\mathrm{La}(\mathrm{Ni}, \mathrm{Fe}) \mathrm{O} 3-\delta$ Cathode for Solid Oxide Fuel Cells," ACS Appl. Mater. Interfaces, 12 [5] 5730-8 (2020).
